\title{
Grammatical Errors of Bilingual 1 Francophone Learners of English in the University of Yaounde I
}

\author{
Stéphane Céleste Piewo Sokeng \\ University of Yaounde I, Cameroon
}

\begin{abstract}
The paper investigates the difficulties that bilingual level 1 Francophone students in the Department of Bilingual Studies of the University of Yaounde I face in English. Data for the study is the essay of 250 students of the 2013-2014 academic year were brought out through a general essay topic they were asked to write. The essays were manually scored and the errors were classified and tabulated according to their number of frequency in the students' essays. The analysis of their compositions revealed that the informants had evidential shortfalls in English grammar. Findings show that the most salient grammatical errors which were found in the students essays included: verb tense and form, subject-verb agreement, prepositions, word order, plurality, articles, passive voice, auxiliaries and double negation. These results showed that the teaching and learning of English writing skill of secondary students in Cameroonian primary and secondary schools need more reinforcement and development.
\end{abstract}

Index Terms-Francophone, grammatical errors, writing

\section{INTRODUCTION}

Cortés (2005) quotes Odlin (1993) who defines a language transfer as "the influence resulting from similarities and differences between the target language and any other language that has been previously (and perhaps imperfectly) acquired" (p. 240). Globalization has placed a growing importance on the study of the English language. Learners of English can be counted all over the world and so their errors. Prior researches on error analysis show that errors are indispensable since the making of errors can be regarded as an evidence that the learner is learning (Lado, 1957, Corder, 1967). Also, Candling (2001) observes that L2 learner's errors are potentially important for the understanding of the processes of language learning (p. 69). Cameroonian learners of the English language do not escape this rule. The structural differences between the numerous languages that exist in Cameroon has made it difficult for Francophones learning English as their second official language to use the language appropriately. Cameroon adopted French and English as its official languages in 1961 and is one of the most multilingual countries in Africa with over 248 home languages and lingua francas spoken in the territory. English is taught in all French-medium schools as from primary level and vice versa for French in English-medium schools. Francophones and Anglophones still have difficulties in expressing themselves in their second official language. It has even been more difficult for Francophones who, for the most part have a negative attitude towards English (Sokeng, 2011). Lado (1957) claimed that "the student who comes in contact with a foreign language will find some features of it quite easy and others extremely difficult (p.2). Those elements that are similar to his language will be simple for him, and those elements that are different will be difficult". Similar elements in both languages may help the learner achieve a better knowledge while differences may hinder the learning process.

\section{A Historical BaCKGround to THE FiELD OF ERROR ANALYSIS}

Error analysis, a branch of applied linguistics, emerged in the sixties to demonstrate that learner errors were not only because of the learner's native language, but also reflected some universal learning strategies. This was as a reaction to the contrastive analysis theory, which considered interference as the basic process of second language learning. Richards and Schmidt (2010) define Error Analysis (EA) as the study and analysis of the errors made by second language learners (p. 201). EA may be carried out in order to identify strategies which learners use in language learning, to try to identify the causes of learner errors and obtain information on common difficulties in language learning, to act as an aid to teaching or in the preparation of teaching materials.

\section{A. What Is an Error?}

Richards and Schmidt (2010) make a distinction between an error and a mistake. An error results from incomplete knowledge, and a mistake is made by a learner when writing or speaking and is caused by lack of attention, fatigue, carelessness, or some other aspect of performance (p. 201). Hubbard et al. (1983) say all incorrect forms produced by students are errors but it is important to make a difference between genuine errors caused by the lack of knowledge about the target language or incorrect hypotheses about it and mistakes caused by temporary lapses of memory confusion, slips of the tongue and so on (p. 134). Erdogan (2005) quotes Ellis (1997) who suggests two ways to distinguish between an error and a mistake: the first one is to check the consistency of learner's performance. If he 
sometimes uses the correct form and sometimes the wrong one, it is a mistake (p. 263). However, if he always uses it incorrectly, it is then an error. The second way is to ask learner to try to correct his own deviant utterance. Where he is unable to, the deviations are errors; where he is successful, they are mistakes.

\section{B. Sources of Errors}

We distinguish between two sources of errors: interlingual transfer and intralingual transfer:

\section{a- Intralingual transfer}

Richards and Schmidt (2010) define an intralingual error as one which results from faulty or partial learning of the target language, rather than from language transfer (p. 294). Intralingual errors may be caused by the influence of one target language item upon another. For example, a learner may produce He is comes*, based on a blend of the English structures He is coming, He comes. Shekhzadeh and Gheichi (2011: 161) say intralingual transfer is mostly caused by overgeneralization (or ignorance of rule restriction) and transfer of training (when teaching creates language rules that are not part of the L2)

\section{b- Interlingual transfer}

From the same source (ibid), an interlanguage error is an error which results from language transfer, that is, which is caused by a transfer of similar rules from the learner's native language. For example, the incorrect French sentence Elle regarde les* ("She sees them"), produced according to the word order of English, instead of the correct French sentence Elle les regarde (literally, "She them sees"). Interlingual errors may occur at different levels such as transfer of phonological, morphological, grammatical and lexica-semantic elements of the native language into the target language (Shekhzadeh and Gheichi, 2011).

\section{LITERATURE REVIEW}

The literature on error analysis by Francophone students learning English in Cameroon is vast even though most of it focuses on only specific aspects. Lebe (2001) discusses the use of English auxiliary verbs by Francophone learners of English. He reveals that the informants could use effectively the present continuous and the present perfect continuous but they faced a lot of difficulties using the future continuous, the past perfect continuous, the past continuous, the future perfect continuous and the passive voice. They could use the verb 'to do' in the present tense and past tense in declarative structures but had some problems in interrogative and negative sentences. He mentioned the course textbooks as one of the source of the errors but also students' inabilities to understand their lessons, poor motivation and incompetent and untrained teachers. Wochiwo (2009) goes in the same line and adds that the errors of Francophones can be attributed to the fact that there is no equivalence in French of certain tenses like the present perfect. Dayang (2005) found that some Francophone students 'underused' prepositions because of a lack of motivation on their part, whereas motivated students who used these prepositions encountered problems in their use because of the misunderstanding of their use due to poor teaching methods. Other authors investigated into some grammatical problems of Francophones learners of the English language in Cameroon like Etame (2005), Fornkwa (2013), Kameni (2004), etc....

At the international level many recent publications have been published on the errors of learners of English as a foreign language. Sarko (2008) discusses the morphophonological or syntactic transfer in the acquisition of articles by Syrian Arabic speakers. He finds that Syrian Arabic speakers transfer L1 syntactic properties into their L2 grammar. Isabelli-García and Slough (2012) goes further by distinguishing the mean rate of missed obligatory use of the definite article which are cultural, situation, structural and textual. They affirm that time spent studying the English non-generic definite article does increase accuracy rates across all these categories. Al-Badawi (2012) analyses the phonetic, morphological and syntactic errors in English of some Saudi BA students. His results reveal that most syntactic errors committed by these students can be attributed to a lack of L2 knowledge: $42.5 \%$ of the sample violated subject-verb agreement in noun phrases due to lack of knowledge of the plural system of English nouns, 57.5\% failed to use the adverbial 'because' due to lack of knowledge of cause-effect adverbial clauses, $50 \%$ failed to use the indefinite article (a/an) due to lack of awareness that each noun phrase must be preceded by a determiner, and $70 \%$ erroneously substituted the indefinite article (a/an) for the definite article (the). A significant number also used certain prepositions incorrectly due the absence of certain adverbs of place in Arabic (57.5\%). A second group failed to use the correct time sequence due to lack of awareness that all the verbs in a time sequence in a sentence must carry the same tense as that of the first verb (50\%). A third group failed to use (50\%) or erroneously repeated $(27.5 \%)$ the auxiliary 'be' due to the absence of this auxiliary in Arabic. A fourth group failed to use the restrictive relative pronoun 'who' after the noun phrase due to lack of awareness that each noun phrase that constitutes a clause in the embedded position must be followed by a relative pronoun $(40 \%)$ and a last group added another noun phrase of the same category to the subject of a sentence (30\%). Mungungu (2010) investigated into the writing of ESL of Namibian learners. He reveals that native speakers of Afrikaans, Silozi and Oshiwambo had difficulties with English spelling, tenses, prepositions and articles respectively.

The present paper is an analysis on the grammatical errors made by first Francophones learners of English in Cameroon, focusing on a general overview of grammar than limiting itself to specific aspects. Also, it tries to give a 
global picture of the errors of Francophones who obtained the best marks (from 14/20 upwards) at the English paper at the Baccalauréat A4 (GCE Advanced Level-Humanities) at the end of the secondary level of education.

\section{METHODOLOGY}

This section provides information on the informants (4.1) and the techniques and data collection instruments (4.2).

\section{A. Informants}

The population of the study consisted of 250 first year Francophone students from the Department of bilingual studies, aged between 16 to 20 years. They were selected at random from students who registered in the 2013-2014 academic year. Out of the 250 students who participated, 147 were female and 103 were male. The participating students have been studying English as a school subject in primary and secondary school for more than 7 years. French is their first official language and English their second official language.

\section{B. Data and Method of Analysis}

Data is derived from students' essays on the following topic: How did you spend your Christmas holiday? It should be noted that a general topic was chosen because it was clear, short, simply stated, it encouraged students to write and the aim was not the answer itself but the way the informants expressed their ideas. The test was given for 2 hours and the scripts were corrected. Each error was identified and classified and a total of 908 errors were identified (see Table 1 below).

\section{Presentation, analysis and discussion of the data}

Table 1 presents the statistical results of the grammatical errors made by the informants:

TABLE 1:

TOTAL NUMBER OF GRAMMATICAL ERRORS

\begin{tabular}{|l|l|l|l|}
\hline & Grammatical errors & Number of errors & Percentage \% \\
\hline 1. & Verb Tense and Form & 208 & 23 \\
\hline 2. & Subject/Verb Agreement & 202 & 22 \\
\hline 3. & Prepositions & 163 & 18 \\
\hline 4. & Word Order & 116 & 13 \\
\hline 5. & Plurality & 84 & 09 \\
\hline 6. & Articles & 48 & 05 \\
\hline 7. & Passive Voice & 45 & 05 \\
\hline 8. & Auxiliaries & 28 & 03 \\
\hline 9. & Double Negation & 14 & 02 \\
\hline Total & 908 & 100 \\
\hline
\end{tabular}

As we can see on Table 1, most students make grammatical errors at the level of verb tense and form (23\%), subject/verb agreement (22\%), prepositions (18\%), word order (13\%), plurality (9\%), articles (5\%), passive voice (5\%), auxiliaries $(3 \%)$ and double negation $(2 \%)$ respectively.

\section{Identification of the errors}

In order to analyse the types of grammatical errors in students' essays, the errors were identified and categorized into different error types by the researcher. The errors were counted and rated in percentage of frequency. They were divided into two groups; interlingual errors and intralingual errors. A total of 908 errors were counted in this study (Table: 1). Since the aim of this study is on grammatical errors regardless of other writing skills, such as cohesion, idea expression and organisation, the essay scoring involved error frequency counts for grammatical errors only.

\section{Analysis of the various errors in the informants' essays}

The main objective of this study is to analyse students' grammatical errors and to investigate the reasons behind this frequent occurrence and find a solution to minimize committing such errors. Ellis (1997) and Hubbard et al. (1996) gave practical advice and provided clear examples of how to identify and analyse learners' errors p. 16-19, p. 135). The initial step requires the selection of a corpus of language followed by the identification of errors. The errors are then classified. The next step, after giving a grammatical analysis of each error, demands an explanation of different types of errors. Thus, the students were asked to answer a general question and the scripts were corrected. Each error was identified on each script and was classified according to type of error (subject/verb agreement, passive voice, auxiliaries, verb tense and form, word order, prepositions, plurality, articles and double negation.

3.1. Grammatical Errors

It cannot be argued that grammar is very important in the understanding of a second language. However, most Francophone Cameroonian learners of English as a foreign language view the study of grammar as boring and not beneficial (Sokeng, 2006, Tagne, 2011). Even though Cameroonian students' general expectations from English for Academic Purpose are very high (Tagne, 2011), they find English grammatical rules intricate and they prefer to copy notes from other students. One of the misconceptions among Francophone level 1 bilingual students is the belief that without mastering most English grammatical rules they will not be able to communicate in English. 
Examples of the grammatical types of errors all drawn directly from the essay corpus (Topic: How did you spend your Christmas holidays?) were given below in italics along with the correct word or form immediately following each example.

a- Verb Tense and Form

The most common type of error made by students in the study group is Verb tense and form. The bulk of error rates in this section occurred within the error category of verbs, with 208 errors (23\%). This finding reveals that the use of verb tense and their form is still a nightmare to most Francophones learning the English language. The tenses most commonly misused were the simple present tense, past tense, future tense, past perfect and the progressive. French and English verb grammar have considerable areas of overlap. A typical problem is the wrong choice of tense. There are frequent occasions when French uses a different tense to convey a particular meaning than English. Misuse of the simple present tense in the third person singular is the one mostly highlighted. Below are some examples:

1) When strangers come, my brother go to buy drinks for everybody. Me, I serve food.

2) Christmas collocate with food, fun and enjoyment. It is the period I prefer in the year.

3) We prayed God that he keep our family. We also pray for the new year.

In the above examples, the students have poorly used the simple present tense because they have not added the $-\mathrm{s}$ in the third person. The correct answers are: 'goes' for the first sentence, then 'collocates' and 'keeps'.

Another difficulty faced by the informants was the use of the correct form of the past. Some used the present perfect instead of the simple past or the past progressive instead of or the present perfect progressive, etc. or they simply miss all as shown below:

4) I have been spent my own holidays in the village with my grand-mother.

In this example, the informant is trying to express an event that took place in the past with an emphasis on the fact and not the duration, in this case, the simple past was more adequate. The sentence should read: I spent my own holidays in the village with my grand-mother.

Just like in the examples that follow where the informant used the simple present instead of the past tense.

5) Holiday is a short period of time make free by the government for workers and students to be on rest....

6) Last holidays, I enjoy myself very well, I eat a lot. It was very good.

7) I have been travelled from Yaounde to Bafoussam on the $22^{\text {nd }}$ of December and I reach there early. Immediately I run to see my best friends.

The correct answers are: 'made', 'enjoyed', 'ate', 'travelled', 'reached' and 'ran'.

Other examples are:

8) At 2 o'clock I started visited my friends, we were talked about what we are doing at the university. One, Geography and the other French.

9) My holidays had begun well and ended bad. This is because of my grand-mother.

The sentences should read: 'visiting', 'talked', 'began'.

\section{b- Subject-Verb Agreement}

Subject-verb agreement is the second most common type of error made by the students. In this case, the subject and the verb phrase in the English sentence should agree in number and person. This was the area with the highest sampling with a total of 202 attempts, which is $22 \%$. It is clear that the students lack a basic understanding of subject-verb agreement in English grammar.

Examples of errors in Subject-Verb Agreement:

i. plural subject does not agree with singular verb:

10) My holidays was very nice.

11) I know my family and my friends waits for me at home.

12) Every Sunday, people sings nice songs in my church.

13) My mother said spices was not enough in the chicken.

14) Prayers in January with the family is very important.

In the above examples, the plural subject does not agree with singular verb. The correct forms should read 'were', 'wait', 'sing', 'were' and 'are'.

ii. Singular subject does not agree with plural verb:

15) When my friends tell me that results, results, this mean that I have to go.

16) My father encourage me to always work hard in class. In the future I would like to become a minister.

17) The $25^{\text {th }}$, my elder sister's daughter $d o$ all the cooking. There is ndolè, rice, chicken, etc.

18) My village were situated in the centre region. Big but only 700 people.

19) I had breakfast which were made of eggs, milk, chocolate and bread. In Yaoundé I cannot eat like that.

20) It were not easy to get to Bafia because there was a lot of traffic and the price of cars always add during holidays. But finally I saw a bus.

Here, the singular subject does not agree with the verb in the plural form. Correction of sentences 15, 16, 17, 18, 19 and 20 are 'means', 'encourages', 'does', 'was', 'was' and 'was'. In French, there is no third person singular with a -s at the end of the verb in the present tense, that probably explains why the informants systematically forget to put an $-\mathrm{s}$ in the third person singular in the present tense. 


\section{c- Prepositions}

Prepositions express time, space, direction, quantities, etc. We noticed while reading the writing of the students that the use of prepositions was a serious problem to them. Mbia (2007) found that $51.6 \%$ of Francophones writing the English language paper at the Baccalauréat could not use prepositions properly (p. 44). Since prepositions have several functions (time, space, quantities, direction, etc.), it is advisable to learn them following their contextual occurrences. $18 \%$ of our informants could not use prepositions.

Below are some of the most recurrent cases:

21) During holidays, I prefer to go for the village to see my grand-mother. Here there is no food the way I want.

'to' expresses a direction, a place, we go 'to' a specific place. It is supposed to be 'to'.

22) My aunt said we have to cook our fat chicken. My brother started to search the chicken and it was in the roof.

We use 'on' when the meaning is clearly 'on top of'. For example, on a table, on a bicycle, but we use 'in' when 'on top of' is not appropriate. For example, in a car, in an airplane.

Another difficulty was the use of prepositions at the level of phrases as shown in the following examples:

23) Each time I travel to Maroua, I am always afraid by the long distance. After the train it is the bus and after a taxi.

24) My family and I like going at church on Christmas day. We meet all our friends there and we pray God.

25) I left Yaounde to go back in Bertoua where my family is. I was not very sad, just a bit.

The sentences should read 'afraid of', 'going to' and 'to go back to'.

We also noted some cases of missing prepositions as seen in the following examples:

26) I was looking my phone when I realized it had disappeared. There are many thieves in 'Buca Voyages' during holidays.

27) I would like visit Kribi next year because my best friend lives there. She said it is very beautiful and there are many whites.

28) In the beginning of 2014 , I can say that 2013 was and will be one of the best of my life.

In (26) the preposition for is missing as we say 'looking for', just like (like to' (27) and 'At the beginning'(28).

Mbia (2007) says this wrong use of prepositions is caused by a poor mastery of the English language since there are no standard rules to help learners use prepositions correctly (p. 44).

\section{d- Word order}

As Choroleeva (2011) says, there are modifications to word order attributable to the influence of French, most often illustrated in the placement of adjectives after nouns in noun phrases. In French, most adjectives go after the word they modify. Such word order is not typical of English where few clichéd phrases denoting diplomatic ranks feature nouns in the primary position. Most English sentences conform to the SVO word order. This means that the subject comes before the verb, which comes before the object, this pattern is the same in French but we still noticed some difficulties at the sentence level and of the correct adjective order. We counted 116 errors, that is, $13 \%$ of the total number of errors. Below are reproduced some:

29) On the $1^{\text {st }}$ of January, I visited my friends old from secondary school. We were all happy and we talked about our schools.

In the above example, the adjective is describing the noun 'friend' so in this case it has to be in front: old friends. Here are other examples:

30) I also have remarked that my brothers and sisters are now independent. They grow very fast. Tomorrow they will be big men and women!!!

31) I eat never on Christmas day because I will be hungry on the $26^{\text {th }}$. I prefer to eat just a bit and drink a bottle of 'Top Ananas'.

The sentence (30) should read: have also remarked and sentence (31): I never eat.

In the example that follows the order of the adverb 'too much' is not proper. This is probably due to a French linguistic interference.

32) During Christmas, I have too much eaten and now I am fat!

The correct answer should read: have eaten too much

\section{e- Plurality}

Plurality refers to the form of a noun that typically denotes more than one person, thing, or instance. It contrasts with singular. 9\% percent, that is 84 errors were discovered in the scripts of the informants. Some examples of the most recurrent errors are reproduced below:

* General rule: suffix $-\mathrm{s}$ :

33) The DJ played many song that I like during the ceremony. For example Lady Ponce, Majoie, DJ Benaud....

34) I bought two new shoe. One for December and the other for January.

35) My mother bought many present for the family. My father a watch, my junior brother a game and me a small radio.

The correct plural should be 'songs' (33), 'shoes' (34) and 'presents' (35).

* After $s, c h, x, z$ the plural is formed by adding $e s$ :

36) My sister asked me to remove all the dishs on the table.

37) I could hear music in all church in our quarter. 
38) The gifts were in beautiful box.

The correct plural form should read: 'dishes' (36), 'churches' (37) and 'boxes' (38)/

* Uncountable nouns (also called mass nouns or non-count nouns)

39) I do not usually drink much waters I prefer alcohol. I cannot see 'Mützig' and I drink 'Tangui'!

40) There was too much foods and drinks in our house. Everywhere there was something to eat and drink.

It seems from our observation that only few students master the rules applied in the formation of the plural case in English. This is a basic rule that was taught in primary school and in secondary school. (39) should read water and (40), food. Kouatie (2008) in her findings tries to explain that by saying that students do not attend English classes and are not, for the majority interested in learning English in secondary school (p. 65). They have a negative attitude towards the language and it affects their performance.

\section{f- Articles}

Articles are a sub-class of determiners. Quirk (1978) makes a distinction between specific and generic reference (p. 67). Generic reference is used to denote what is normal or typical for members of a class. A definite article is used when our hearer or reader knows exactly what we mean and indefinite articles (a, an) refer to a thing which is not specific. The latter are used with singular countable nouns but not with plural nouns. We have noticed that even though the rules behind the use of articles seem to be vast; our informants had acquired them easily since only $5 \%$ of them made some errors as can be seen below:

(1) Misuse of the article 'the'

41) I have worked hard all the day.

42) I danced all the night with my friends at Katios.

'The' is left cut of the expressions 'all day' (41) and 'all night' (42) but it should be used in similar adverbial expressions for other divisions of time: all the morning, all the afternoon, all the evening, all the week.

(2) Misuse of 'a' and 'an'

43) Holiday is $a$ event to unite. People should not be sad and unhappy.

44) My mother had $a$ accident on a bike. The driver of the bike was not vigilant. It is always like that in Douala.

45) An holiday is a period when you rest. You eat, drink and sleep. I like it.

Generally, the correct choice of $a$ and $a n$ depends on the initial sound of a word, not on the initial letter, of the word that they precede. The letter $a$ should be used before all words beginning with a consonant sound except silent $h$ and before words beginning with vowels that represent combined consonant and vowel sounds (university, unit). In sentence 43 it should be an event, in sentence 44, an accident and a holiday in sentence 45.

(3) Absence of an article

46) My father is teacher. I will like to be like him.

Here, the student is supposed to put the article: $a$ teacher. This is probably due to the influence of French since the above sentence in French would be translated: 'Mon père est enseignant'. It is thus an interlingual transfer.

47) Christmas tree is in the parlour. There are many decorations.

48) When I got out bus, they came to kiss me. My father was there, my mother and my brothers and sisters.

In these examples, the articles have been omitted. In sentence 47 the sentence should read: The Christmas tree ... and sentence 48: When I got out of the bus.....

\section{g- Passive voice}

Passive voice was not very present in the essay write-up submitted to the informants. In the few scripts were cases of passive voice were noted, the percentage of errors was (5\%). The number of the total errors found was 45 . Below are reproduced few examples of the errors identified in the use of the Passive Voice:

49) Only two of my brothers were effective participated in the decoration of the tree.

In this example, the informant used two conjugated verbs in the same sentence where there was no need. There is a redundant auxiliary with active voice. The simple present does not use an auxiliary ('be' or 'have'). The informant may not know the correct to be applied in this context. The correct sentence should read: Only two of my brothers participated in the decoration of the tree.

50) The Christmas holiday divide into two periods: Christmas and New Year.

In this example, we observe an incorrect form of the main verb. In this sentence, the holiday period does not 'divide' anything, but it is the period itself which is divided into two distinct periods: The Christmas holiday is divided into two periods: Christmas and New Year.

51) The concert was happened the week of Christmas. It was during 'Yafe'.

Here, there is an incorrect use of the passive with an intransitive verb because it is not possible to use the passive with intransitive verbs (that is those with a direct object. This mistake is probably due to a case of language transfer. The correct form is: The concert happened the week of Christmas.

\section{h- Auxiliaries}

An auxiliary verb helps the main verb. It is also called a "helping verb". With auxiliary verbs, it is possible to write sentences in different tenses, moods, or voices. Auxiliary verbs are: be, do, have, will, shall, would, should, can, could, may, might, must, ought, etc. In the composition given to the informants we notice a wrong use of the following auxiliaries: be, do, have. 
52) The food been cooked and it was good. I liked it.

53) Pamela done all the work and went to YaFe. She said it was fantastic.

54) I have had a beautiful dress for Christmas: blue and white.

55) They cannot imagine how I had been waiting for this moment. No school, no teacher, only food.

56) My uncle been took us to "Tchop et Yamo" where we eat beans and pufpuf. It was my first time.

The students seem to have over-generalised the use of auxiliary verbs. They have difficulties in expressing events that have happened in the past (near or far). In an attempt to show that events happen and happened, the learners get confused in the use of English auxiliaries. The correct forms are 'was' (52), 'did' (53), 'had' (54), 'have been' (55) and 'took' or 'had taken' or 'had eaten' (56).

\section{i- Double negation}

Tubau (2008) quotes Klima (1964) who distinguishes between two types of negation: sentential and constituent (p. 77). Sentential negation negates the sentence as a whole, while constituent negation negates just a constituent. Richards and Schmidt (2010: 390) say the main negator in English is not, often in its contracted form $n$ ' $t$ and combined with an auxiliary, for example: She isn't going. But there are other negators, like never or negation can also be expressed by negative pronouns, e.g.: There was nobody there. Or by negative affixes, e.g.: That was really unkind! The few cases (2\%) we discovered in the compositions of the informants were mostly with the negative pronoun 'nobody'.

Below are some examples of cases of double negation misuse by the informants:

57) My father does not want to see nobody in the parlour as from 10pm, neither me, neither (nor) my brother even during holidays.

58) We hadn't nobody to help us cook New Year's food.

In the above examples, a wrong negative pronoun has been added to the negative element 'not'. Sentence 57 should be: My father does not want to see anybody in the parlour as from 10pm, neither me, neither (nor) my brother even during holidays and sentence 58: We hadn't anybody to help us cook New Year's food.

The results of this study have shown that the informants make a lot of different types of writing errors in general and grammatical errors in particular. The sources of these errors can be interlingual and intralingual. Great care should be taken by anyone writing or speaking English. In order to check that their writing does not contain any grammatical mistakes, learners have to carefully proofread their work and check that all the sentences are well- labelled and stated.

Another recommendation is that it is also best to check using grammar books so as to be really sure that the meaning the learner is trying to pass is clear and the grammar he is using is correct. The best way can be to say in simple ways what the learner has to say.

\section{CONCLUSION}

The study aimed at identifying, describing, categorizing, and diagnosing the type of grammatical errors made by Francophone level I, university students in the department of bilingual studies. As a result, a number of different grammatical errors were found in their English essays. These were limited to nine major errors: verb tense and form, subject/verb agreement, prepositions, word order, plurality, articles, passive voice, auxiliaries and double negation. After analysing the errors, it has been found out that the grammatical errors the students make are classified into two main types: interlingual and intralingual reasons. This result is not satisfactory because these students are supposed to be the best in English in the country because the department of bilingual studies is the only department in the faculty where a student must at least have $14 / 20$ to be selected. Thus, the teaching of the second official language should be reinforced. It should be effective at all the levels of education. Mbangwana (2004) says "an integrated educational system which does not begin at the secondary level will hardly succeed at the higher educational level where students are already adults, with diminishing curiosity and capacity to take up linguistic challenges (p. 23). If this is done properly then the pupils during their full primary school cycle should be able to have a sound basic knowledge of the practical language to which they should have recourse after leaving school and should provide them sound linguistic basis for further studies as they move to secondary schools".

The government should reinforce the teaching of the English language by allocating more periods for the teaching of English and by recruiting more qualified teachers to satisfy the needs of the learner. An accent should be put on basic language skills like listening, speaking, reading and writing. Teachers should be able to not only detect and describe the errors from a linguistic view, but also to understand the psychological reasons for their occurrences.

Correction of errors is as important as identification and description of them. Such research work should help teachers and the government to be aware of the most common and salient grammatical errors students make and they should be able to make use of them in the teaching process appropriately.

\section{REFERENCES}

[1] Al-Badawi, K. (2012) An analysis of phonetic, morphological and syntactic errors in English: a case study of Saudi BA students at King Khalid University. In International Journal of Social Science and Humanity. Vol. 2, No. 6, DOI: 10.7763/IJSSH.2012.V2.165.

[2] Choroleeva, K. (2009). Language transfer: Types of linguistic errors committed by francophones learning English as a second foreign language. In Humanising Language Teaching Magazine. Website: http://www.hltmag.co.uk/oct09/. 
[3] Corder, S. P. (1967). The significance of learners' errors. Cited in J.C. Richards (ed.) 1984, Error Analysis: Perspectives on second language acquisition. London: Longman, (Originally in International Review of Applied Linguistics Vol 5, No 4. pp 19 $-27$.

[4] Cortés, C.N. (2005). Negative language reansfer when learning Spanis as a foreign language. In Interlingüistica. Vol 16, No 1, pp 237-248.

[5] Dayang, C. (2005). Problems of preposition usage by francophone learners of English as a foreign language: The case of 'Terminale' students in L.B.A. and Lycée Général Leclerc. Unpublished D.I.P.E.S. II Dissertation. ENS, University of Yaounde I.

[6] Ellis, R. (1997). Second language acquisition. In Oxford Introduction to Linguistics. Oxford: Oxford University Press.

[7] Erdogan, V. (2005). Contribution of error analysis to foreign language eeaching. Mersin University Journal of the Faculty of Education.Vol 1, No 2, pp 261-270.

[8] Etame, E. G. (2005). Some grammatical problems in the essays of francophone students of the science classes in E.N.S. Yaounde. Unpublished D.I.P.E.S. II Dissertation. ENS, University of Yaounde I.

[9] Fornkwa, M. J. (2013). Aspects of Francophone Cameroon English Inflectional Morphology: The Case of the -s Inflection. In International Journal of English Language Education. Vol 1, No 1, pp. 49- 67.

[10] Hubbard, P. et al. (1983). A Training Course for TEFL. Oxford: Oxford University Press.

[11] Hubbard, P. et al. (1996). A Training Course for TEFL. Oxford: Oxford University Press.

[12] Isabelli-García, C. and Slough, R. (2012). Acquisition of the non-generic definite article by Spanish learners of English as a foreign language. In OnOmázein, Vol 25, No 1.pp. 95-105.

[13] Kameni, T. (2004). The use of English by second year engineering students of Ecole Nationale Superieure Polytechnique (ENSP) Yaounde: An appraisal of problems encountered. Maîtrise Dissertation. University of Yaounde I.

[14] Klima,E.S.(1964).Negation in English. In J.A.Fodor \& J.J.Katz (Eds.). The structure of language. New Jersey: Prentice-Hall.

[15] Kouatie, T. L. (2008). The teaching of English in technical schools in Cameroon: a case study of two schools in Bafang. Unpublished Maîtrise Dissertation. University of Yaounde I.

[16] Lado, R. (1957). Linguistics Across Cultures: Applied Linguistics for Language Teachers. Michigan: University of Michigan Press.

[17] Lebe, J. J. (2001). The use of English auxiliary verbs by francophone learners of English: A case study of 'Seconde' classes in Lycée Général Leclerc, Yaounde.

[18] Mbangwana, N.P. (2004). Cameroon nationhood and official bilingualism: A linguistic juxtaposition? In Revue Internationale des Arts, Lettres et Sciences Sociales (RIALSS). Vol 1, No 1, pp. 15-38.

[19] Mbia, B. L. A. (2007). Language testing at the 'Baccalauréat A4' examination in Cameroon : an evaluation of the reading and essay sections. Unpublished DEA thesis. University of Yaounde I.

[20] Mungungu, S. S. (2010). Error analysis: investigating the writing of ESL Namibian learners. Unpublished MA Dissertation. University of South Africa.

[21] Odlin, T. (1993). Language Transfer: Cross-linguistic Influence in Language Learning. Cambridge, CUP.

[22] Quirk, R. and Greenbaum, S. (1978). University Grammar of English. London: Longman Group Limited.

[23] Richards, J.C. and Schmidt, W. R. (2010). Longman Dictionary of Language Teaching and Applied Linguistics. $4^{\text {th }}$ Edition. Routledge: Pearson Longman.

[24] Sarko, G. (2008). Morphophonological or syntactic transfer in the acquisition of English articles by L1 speakers of Syrian Arabic? In Proceedings of the 9th Generative Approaches to Second Language Acquisition Conference (GASLA 2007). Ed. Roumyana Slabakova et al., pp. 206-217. Somerville, MA: Cascadilla Proceedings Project.

[25] Shekhzadeh, E. and Gheichi, M. (2011). Account of sources of errors in language learners' interlanguage. In 011 International Conference on Languages, Literature and Linguistics IPEDR. Vol.26, pp. 159-162.

[26] Sokeng, P. S. C. (2006). Bilingualism in the University of Yaounde II: The Use of English by Students. Unpublished Maîtrise Thesis. University of Yaounde I.

[27] Sokeng, P. S. C. (2011). The English Language Proficiency of Secondary School Leavers in Cameroon. Unpublished PhD dissertation. University of Yaounde I.

[28] Tagne, S. G. (2011). Evaluating English for Academic Purposes in some Cameroonian Universities, Journal of Education and Practice. Vol 2, No 7, pp. 62-72.

[29] Tubau M. S. (2008). Negative Concord in English and Romance: Syntax-Morphology Interface Conditions on the Expression of Negation. Unpublished Ph.D. Dissertation. Universitat Autònoma de Barcelona.

[30] Wochiwo, P. J. (2009). An investigation into the use of the present perfect tense by 'Terminale' students in Cameroon: A case study of some selected schools in Kribi. Unpublished D.I.P.E.S. II Dissertation. ENS, University of Yaounde I.

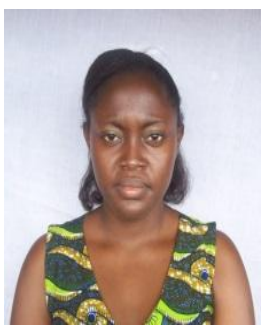

Stéphane Céleste Piewo Sokeng was born in Mbouda, Cameroon, in 1983. She received the B.A. degree in bilingual studies (English and French) from the University of Yaounde I, Cameroon, in 2004, and the Maîtrise, DEA and Ph.D. degrees in English Language from the University of Yaounde I, Cameroon, in 2006, 2007 and 2011, respectively.

In 2007, she joined the Department of Bilingual Studies, University of Yaounde I, as a GRADUATE ASSISTANT, and in 2012 became an ASSISTANT LECTURER. Her current research interests include language teaching and learning, language testing, bilingualism and error analysis. 